Egyptian Journal of Aquatic Biology \& Fisheries

Zoology Department, Faculty of Science,

Ain Shams University, Cairo, Egypt.

ISSN $1110-6131$

Vol. 25(1): 407 - 421 (2021)

www.ejabf.journals.ekb.eg

\title{
Invertebrate Assemblages Associated with Seaweeds at Different locations in the Red Sea, Egypt
}

\author{
Mohsen Y. Omer ${ }^{1, ~}{ }^{*}$, Khaleid F. Abd El-Wakeil' ${ }^{2}$, Hussein N.M. Hussein ${ }^{1}$ \\ and Sarah H. Rashedy ${ }^{1}$ \\ 1. National Institute of Oceanography and Fisheries (NIOF), Red Sea Branch, Egypt. \\ 2. Zoology Department, Faculty of Science; Assiut university, Egypt. \\ *Corresponding Author: Mohsen_102002@yahoo.com
}

\section{ARTICLE INFO}

Article History:

Received: Aug. 30, 2020

Accepted: Jan. 12, 2021

Online: Jan. 26, 2021

Keywords:

Invertebrates

Macroalgae

Epiphytic organisms

Diversity

Community structures

\begin{abstract}
The epiphytic organisms play an important role in nutrient cycles and the diversity of the ecosystem in which they occur. The present study investigated the abundance and community structure of invertebrates associated with seaweeds in the Red Sea, Egypt. Six species of seaweeds; Caulerpa racemosa, Sargassum cinereum, Cystoseira myrica, Halimeda tuna, Hormophysa cuneiformis and Digenia simplex were collected from three different locations; Kalawy Bay, Mangrove area and the National Institute of Oceanography and Fisheries (NIOF) at Hurghada. The study was carried out in winter. The distribution of seaweed was different in the investigated locations. Twenty-six invertebrate species were identified from three locations. At the Mangrove area station, amphipods were the most abundant fauna associated with C. myrica and $H$. cuneiformis, while nematode was the most abundant group associated with C. myrica, H. cuneiformis and $S$. cinereum at Kalawy Bay. At NIOF station, the most abundant organisms on $C$. racemosa and $S$. cinereum were nematode species, while amphipods were the most abundant organisms on C. myrica. The diversity indices revealed that the highest value of species richness was recorded for C. myrica at the Mangrove station, while the highest species richness values for Sargassum cinereum were recorded at Kalawy Bay and NIOF stations. D. simplex and S. cinereum showed the highest similarity according to the abundances of associated epiphytic fauna.
\end{abstract}

\section{INTRODUCTION}

Macroalgae are essential as a living space and asset of nourishment for macrofauna (Österling \& Pihl, 2001; Salovius \& Kraufvelin, 2004; Salovius et al., 2005). Crustaceans, molluscs, and polychaetes are the major animal taxa associated with macrophytes (Taylor \& Cole, 1994), and information considering their spatial and temporal patterns of abundance is necessary to properly understand marine biological systems. The presence of vegetation permits a greater species diversity and an abundance of individuals than the un-vegetated habitats (Sánchez-Moyano et al., 2007) providing suitable microhabitats, nutritional resources, and protection from predators. 
Lots of arguments have been specified for the perception of how the community structure of most benthic marine organisms is reliant on the physical structure given by living beings such as seagrasses by Heck and Crowder (1991), mangroves by Ellison $\boldsymbol{e t}$ al. (1996), reef-building corals by Done et al. (1997), kelps by Graham (2004), and clams by Grabow- ski et al. (2005). Most habitat-forming species harbour diverse assemblages of associated organisms that profit by such refuges from predators or cruel physical conditions (Bracken et al., 2007). A few attempts have been made to detect the connection between geographical changes in algae composition and the patterns of macroinvertebrate diversity and abundance (Russo, 1997; Pereira et al., 2006).

The current study was conducted to investigate the abundance and community structures of invertebrates associated with the marine seaweeds at three locations in the Red Sea, Egypt, comparing the obtained data of the six dominant seaweed species of the studied locations.

\section{MATERIALS AND METHODS}

Study locations: Three sampling locations were selected for the study; Kalawy Bay, 50 $\mathrm{km}$ south Safaga, Mangrove area at $17 \mathrm{~km}$ south Safaga and the National Institute for Oceanography and Fisheries (NIOF), Hurghada branch. Six dominant species of seaweeds were collected from those locations to estimate the abundance and community structures of invertebrates associated with those seaweeds. The sampling was done in winter (2017). The seaweed species under examination were, namely; Hormophysa cuneiformis, Cystoseira myrica, Halimeda tuna, Sargassum cinereum, Digenia simplex and Caulerpa racemosa.

Description of collection's Locations: The first Location was Kalawy Bay located at 50 $\mathrm{km}$ south Safaga $\left(26^{\circ} 31^{\prime} 53.232\right.$ " N, 34 03' 17.334" E) which is a sandy and little rocky beach. Activities there include diving and snorkeling. During the sampling period, three species of seaweed were recorded, namely, $H$. uneiformis, $C$. myrica and $S$. cinereum. The second was the Mangrove area located at $17 \mathrm{~km}$ south Safaga City (26 37' 06.030" $\mathrm{N}, 34^{\circ} 00^{\prime} 26.808^{\prime \prime} \mathrm{E}$ ). It is distinguished by Mangrove trees (Avicennia marina) and the tidal zone reaching about $100 \mathrm{~m}$ width. A collection of three species of seaweeds $(C$. myrica, H. cuneiformis and H. tuna) was gathered from the second site. The third station was in front of NIOF located at the northern tip of the Red Sea, $5 \mathrm{~km}$ away from the center of Hurghada City $\left(27^{\circ} 17^{\prime} 6.39^{\prime \prime} \mathrm{N}, 33^{\circ} 46^{\prime} 28.93^{\prime \prime}\right.$ E). NIOF location is characterized by a long patchy reef, representing the front edge of a wide and shallow reef which is flat with many depressions and lagoons. Four species of seaweeds $C$. racemosa, S. cinereum, $C$. myrica and $D$. simplex were found in that location. 


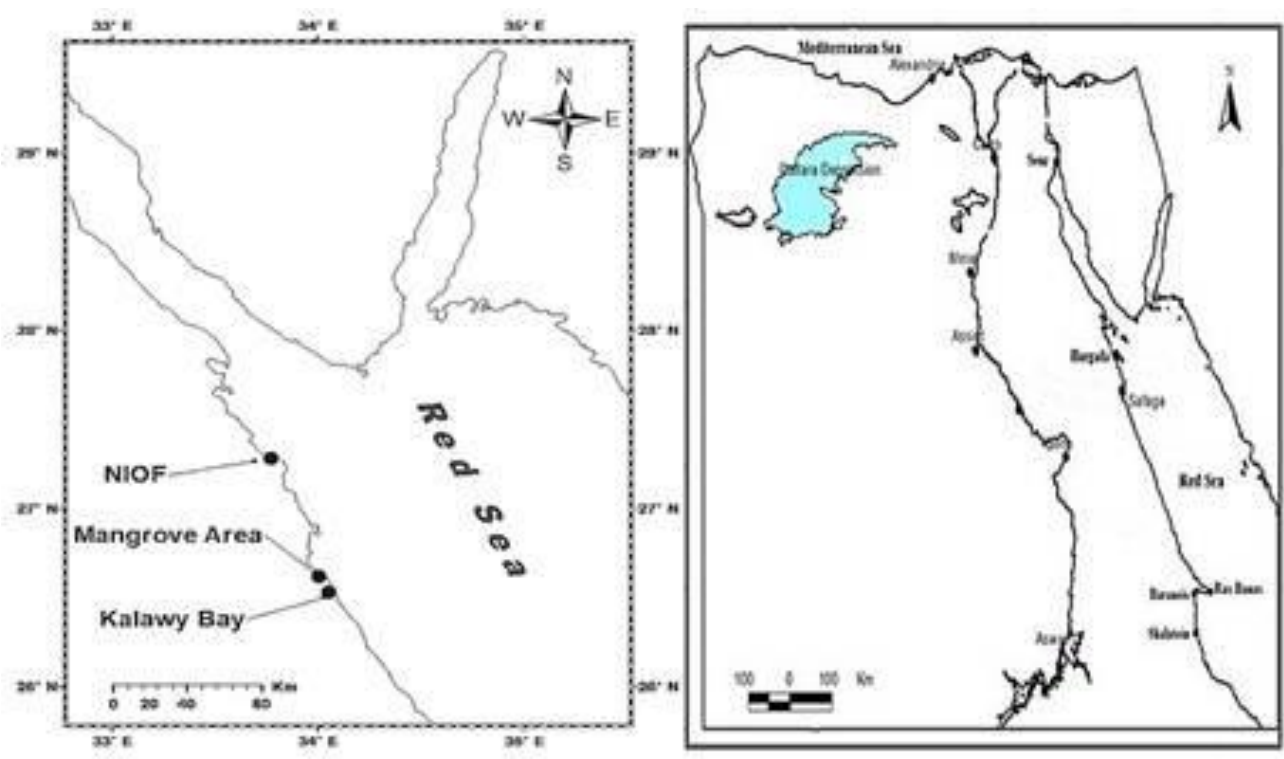

Fig. 1. A map showing the sampling locations; NIOF, Mangrove area and Kalawy Bay

Each of the fresh seaweed thallus was weighed and washed carefully with water in a plastic dish. The water was filtered with $55 \mu$ plankton net for each algae species. Fine forceps were used to pick macro invertebrates. The volume of filtered water was reduced to $100 \mathrm{ml}$ and preserved with $5 \%$ formalin solution. Sorting and identification were performed using a dissecting microscope. Each zooplankter was counted separately using a binocular microscope (40X). The collected zooplankton species were identified according to the method of Tregouboff and Rose (1957), Mori (1964), Gonzalez and Bowman (1965), Williamson (1967), Bradford-Grieve (1972a, 1994b), Newell and Newell (1977), Bradford-Grieve and Jillett (1980), Bradford et al. (1983), Michel et al. (1986), and Heron and Bradford-Grieve (1995).

Physicochemical parameters of water were measured during sampling. Water temperature, $\mathrm{pH}$, conductivity, dissolved oxygen (DO), salinity, turbidity and conductivity were all measured using "YSI multimetre", while $\mathrm{pH}$ was measured by using Jenway Ltd., Model 350-pH-metre. Surface water samples were collected for chemical analysis. Chemical parameters measured include ammonia $\left(\mathrm{NH}_{4}\right)$, nitrate $\left(\mathrm{NO}_{3}\right)$, nitrite $\left(\mathrm{NO}_{2}\right)$, phosphate $\left(\mathrm{PO}_{4}\right)$ and silicate $\left(\mathrm{SiO}_{2}\right)$. All chemical analytical methods were carried out according to APHA. (2005).

\section{Data Analysis}

Range, mean and standard deviation of data were estimated using Microsoft Office Excel (2019). Diversity indices, which includes Shannon-Wiener diversity index and species richness, were used to estimate the species diversity across the study locations (equation 1): 


$$
H=-\sum_{i=1}^{s} P i \operatorname{LnPi}
$$

Where $\mathrm{pi}=$ The total number of species; $\mathrm{LnPi}=$ The natural logarithm of this proportion, according to Shannon (1948).

The similarity of the invertebrate community, that was found attached to the studied seaweed species, was estimated using the Bray-Curtis similarity metric index, applied after $\log 10(x+1)$ transformation of the data to reduce the influence of the few high abundant taxa. To explore the effect of the physicochemical parameters on the invertebrate species, the canonical correspondence analysis (CCA) was used.

\section{RESULTS}

Table 1 shows summarized data of the physicochemical parameters at the three investigated locations.

Table 1. Mean, standard deviation (SD) and range (minimum and maximum) of the water physicochemical parameters at the three studied locations at the Red Sea.

\begin{tabular}{|c|c|c|c|c|c|}
\hline Parameters & Locations & Mean & SD & Minimum & Maximum \\
\hline \multirow{3}{*}{ Temperature } & Mangrove & 17.59 & 0.01 & 17.58 & 17.60 \\
\hline & $\begin{array}{c}\text { Kalawy } \\
\text { Bay }\end{array}$ & 20.51 & 0.01 & 20.50 & 20.52 \\
\hline & NIOF & 20.93 & 0.06 & 20.90 & 21.00 \\
\hline \multirow{3}{*}{$\mathrm{pH}$} & Mangrove & 7.82 & 0.05 & 7.76 & 7.86 \\
\hline & $\begin{array}{c}\text { Kalawy } \\
\text { Bay }\end{array}$ & 8.29 & 0.04 & 8.25 & 8.32 \\
\hline & NIOF & 8.40 & 0.02 & 8.38 & 8.42 \\
\hline \multirow{3}{*}{ Conductivity } & Mangrove & 62.11 & 0.01 & 62.10 & 62.12 \\
\hline & $\begin{array}{c}\text { Kalawy } \\
\text { Bay }\end{array}$ & 62.81 & 0.01 & 62.80 & 62.82 \\
\hline & NIOF & 62.71 & 0.01 & 62.70 & 62.72 \\
\hline \multirow{3}{*}{ TDS } & Mangrove & 40.36 & 0.01 & 40.36 & 40.37 \\
\hline & $\begin{array}{c}\text { Kalawy } \\
\text { Bav }\end{array}$ & 40.82 & 0.01 & 40.81 & 40.82 \\
\hline & NIOF & 40.85 & 0.01 & 40.84 & 40.86 \\
\hline \multirow{3}{*}{ Sal. } & Mangrove & 41.81 & 0.01 & 41.80 & 41.82 \\
\hline & $\begin{array}{c}\text { Kalawy } \\
\text { Bay }\end{array}$ & 42.38 & 0.01 & 42.37 & 42.39 \\
\hline & NIOF & 42.61 & 0.01 & 42.60 & 42.62 \\
\hline
\end{tabular}




\begin{tabular}{|c|c|c|c|c|c|}
\hline \multirow{3}{*}{ Turb } & Mangrove & 7.94 & 0.74 & 7.24 & 8.71 \\
\hline & $\begin{array}{c}\text { Kalawy } \\
\text { Bay }\end{array}$ & 7.25 & 0.07 & 7.17 & 7.30 \\
\hline & NIOF & 8.30 & 0.85 & 7.32 & 8.86 \\
\hline \multirow{4}{*}{ DO } & Mangrove & 7.20 & 0.10 & 7.10 & 7.30 \\
\hline & $\begin{array}{c}\text { Kalawy } \\
\text { Bay }\end{array}$ & 6.67 & 0.15 & 6.50 & 6.80 \\
\hline & NIOF & 7.30 & 0.10 & 7.20 & 7.40 \\
\hline & Total & 7.06 & 0.31 & 6.50 & 7.40 \\
\hline \multirow{3}{*}{$\mathrm{NH}_{4}$} & Mangrove & 0.54 & 0.24 & 0.32 & 0.80 \\
\hline & $\begin{array}{c}\text { Kalawy } \\
\text { Bay }\end{array}$ & 0.83 & 0.18 & 0.65 & 1.01 \\
\hline & NIOF & 0.52 & 0.19 & 0.37 & 0.73 \\
\hline \multirow{3}{*}{$\mathrm{NO}_{3}$} & Mangrove & 0.17 & 0.21 & 0.04 & 0.41 \\
\hline & $\begin{array}{c}\text { Kalawy } \\
\text { Bay }\end{array}$ & 0.04 & 0.01 & 0.04 & 0.05 \\
\hline & NIOF & 0.04 & 0.02 & 0.03 & 0.06 \\
\hline \multirow{3}{*}{$\mathrm{NO}_{2}$} & Mangrove & 0.02 & 0.01 & 0.02 & 0.03 \\
\hline & $\begin{array}{c}\text { Kalawy } \\
\text { Bay }\end{array}$ & 0.03 & 0.01 & 0.02 & 0.03 \\
\hline & NIOF & 0.03 & 0.01 & 0.02 & 0.03 \\
\hline \multirow{3}{*}{$\mathrm{PO}_{4}$} & Mangrove & 3.44 & 0.61 & 3.00 & 4.14 \\
\hline & $\begin{array}{c}\text { Kalawy } \\
\text { Bay }\end{array}$ & 3.31 & 0.66 & 2.76 & 4.04 \\
\hline & NIOF & 2.85 & 0.15 & 2.71 & 3.00 \\
\hline \multirow{3}{*}{$\mathrm{SiO}_{2}$} & Mangrove & 3.57 & 0.66 & 3.11 & 4.33 \\
\hline & $\begin{array}{c}\text { Kalawy } \\
\text { Bay }\end{array}$ & 4.46 & 0.49 & 4.00 & 4.98 \\
\hline & NIOF & 5.39 & 0.14 & 5.23 & 5.49 \\
\hline
\end{tabular}

*(TDS) Total Dissolved Salts, (Sal) Salinity, (Turb) Turbidity

\section{Invertebrates Community Composition}

A total of 26 invertebrate species were collected from three locations at the Red Sea namely; Caulerpa racemosa, Sargassum cinereum, Cystoseira myrica, Halimeda tuna, Hormophysa cuneiformis, and Digenia simplex. At NIOF station, 18 invertebrate species were recorded, while both Kalawy bay and Mangrove area recorded 17 species. Amphipods larvae were the most abundant organisms at the Mangrove area, which were associated with $C$. myrica and $H$. cuneiformis, comprising $34 \%$ and $25 \%$, respectively, of the total species encountered, while the most abundant species on $H$. tuna was nematodes, which amounted to $38 \%$ as shown in Table (2). The most abundant species on 
C. myrica, H. cuneiformis and S. cinereum at Kalawy Bay area was nematode, which amounted to $39 \%, 26 \%$, and $27 \%$, respectively, of the total encountered species (Table 3). At NIOF area, nematode was the most abundant species on $C$. racemosa and $S$. cinereum, which comprised $31 \%$ and $14 \%$ of the total encountered species. Moreover, the most abundant species on $C$. myrica and $D$. simplex were amphipod larvae and Cypridina species, which comprised $42 \%$ and $23 \%$, respectively (Table 5). Invertebrate assemblage similarity was high within the seaweed species; D. simplex and $S$. cinereum $(>75 \%)$ came from a pool of 26 invertebrate taxa (Fig. 2).

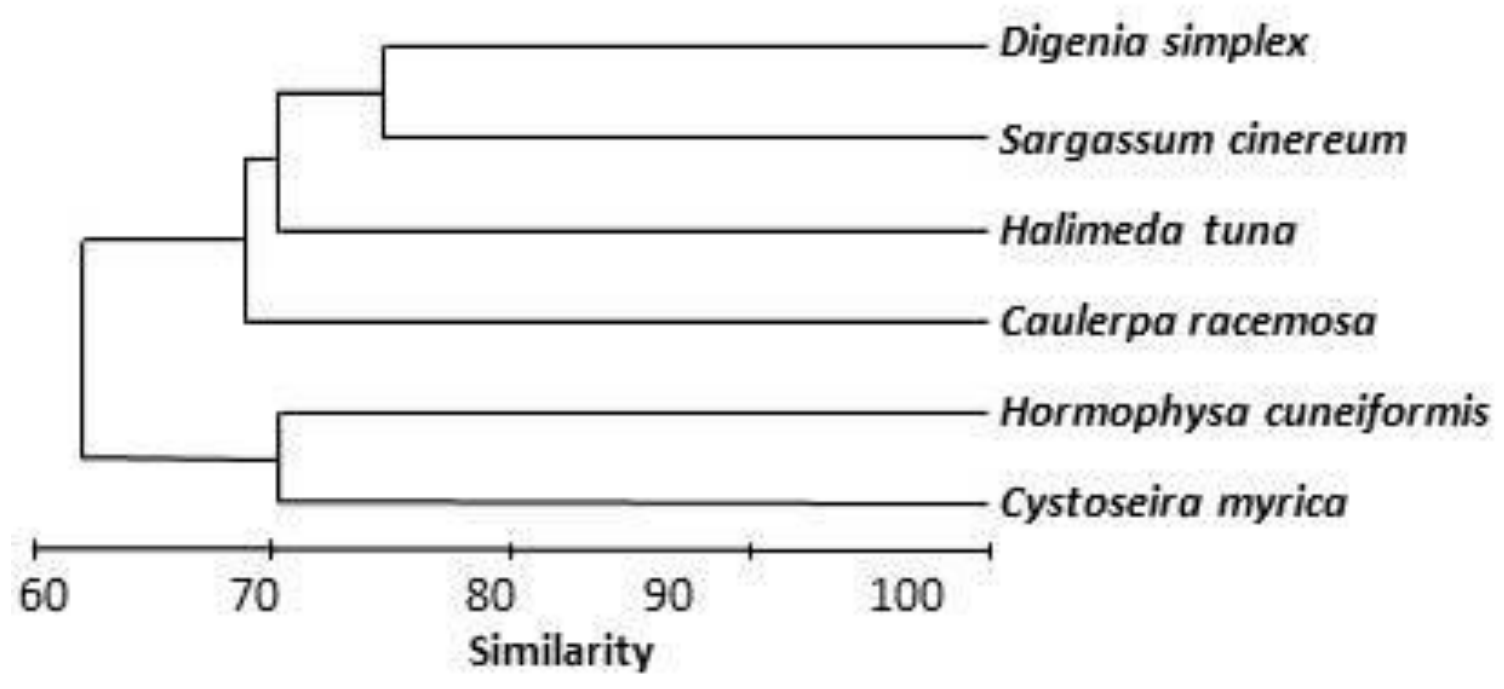

Fig. 2. Dendrogram of seaweed species clusters identified from the Bray-Curtis similarity matrix.

The invertebrate species that contributed most to similarity within clusters were; Acrocalanus sp, and Stenosemella ventricosa (100\%) within all other invertebrate groups (Fig. 2). 


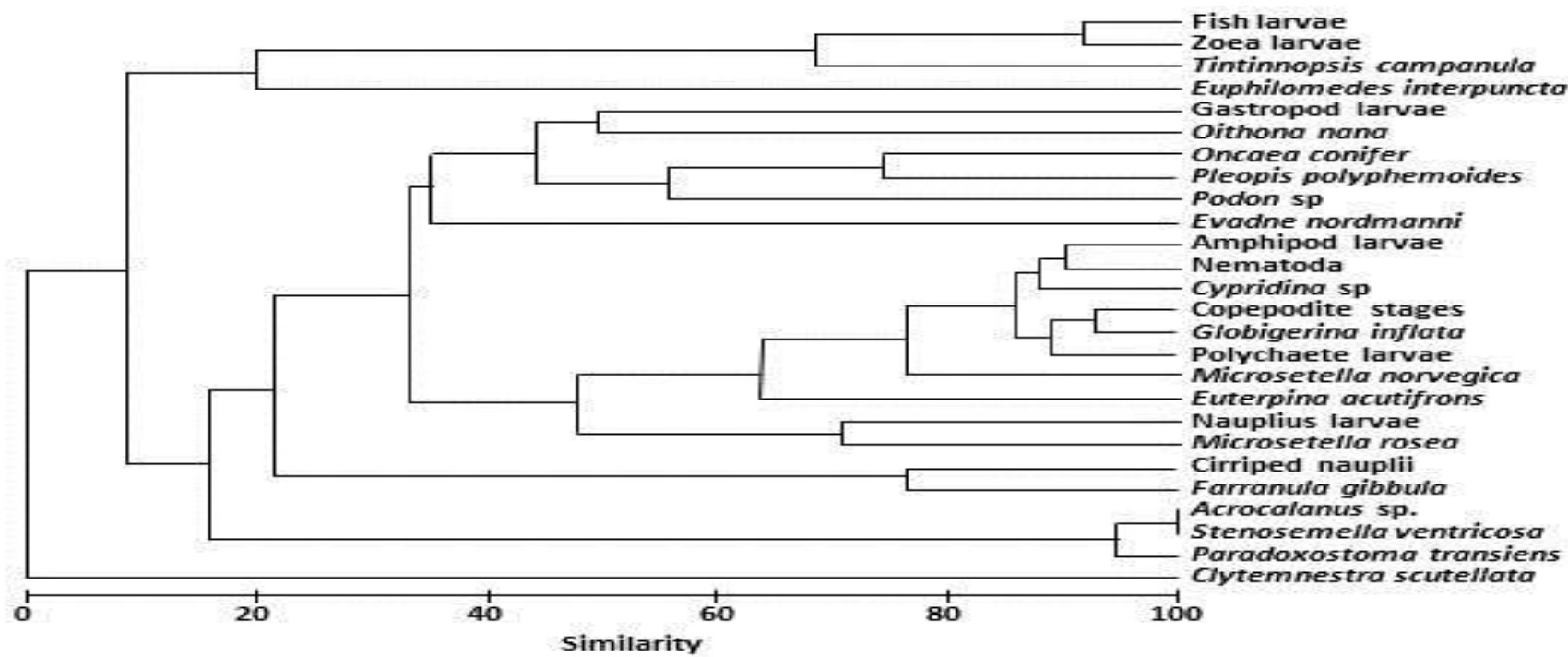

Fig. 3. Dendrogram of invertebrate species clusters identified from the Bray-Curtis similarity matrix of $\log 10$ (x11) transformed invertebrate abundance data, using unweighted pair group average sorting.

Table 2. Density, (Indv. /g: individual per gram) and relative abundance (RA) of the recorded invertebrate attached to Cystoseira myrica, Hormophysa cuneiformis and Halimeda tuna at the Mangrove area.

\begin{tabular}{|c|l|c|c|c|c|c|c|}
\hline \multicolumn{2}{|c|}{ Seaweed species } & C.myrica & RA & H.cuneiformis & RA & H.tuna & RA \\
\hline \multicolumn{2}{|c|}{ Invertebrate Taxa } & Indv. / g & $\%$ & Indv. / g & $\%$ & Indv. / g & $\%$ \\
\hline 1 & Stenosemella ventricosa & 42 & 1.75 & 0 & 0.00 & 0 & 0.00 \\
\hline 2 & Globigerina inflata & 63 & 2.62 & 74 & 8.52 & 61 & 10.63 \\
\hline 3 & Nematoda sp. & 167 & 6.96 & 88 & 10.13 & 217 & 37.80 \\
\hline 4 & Pleopis polyphemoides & 63 & 2.62 & 44 & 5.06 & 0 & 0.00 \\
\hline 5 & Podon sp. & 0 & 0.00 & 15 & 1.73 & 0 & 0.00 \\
\hline 6 & Evadne nordmanni & 0 & 0.00 & 44 & 5.06 & 0 & 0.00 \\
\hline 7 & Acrocalanus sp. & 42 & 1.75 & 0 & 0.00 & 0 & 0.00 \\
\hline 8 & Paradox ostomatransiens & 63 & 2.62 & 0 & 0.00 & 0 & 0.00 \\
\hline 9 & Oithona nana & 63 & 2.62 & 29 & 3.34 & 17 & 2.96 \\
\hline 10 & Oncaea conifer & 0 & 0.00 & 29 & 3.34 & 0 & 0.00 \\
\hline 11 & Euterpina acutifrons & 63 & 2.62 & 59 & 6.79 & 0 & 0.00 \\
\hline 12 & Microsetella norvegica & 375 & 15.62 & 0 & 0.00 & 61 & 10.63 \\
\hline 13 & Copepodite stages & 167 & 6.96 & 74 & 8.52 & 35 & 6.10 \\
\hline 14 & Cypridina sp. & 354 & 14.74 & 103 & 11.85 & 87 & 15.16 \\
\hline 15 & Amphipod larvae & 813 & 33.86 & 221 & 25.43 & 61 & 10.63 \\
\hline 16 & Polychaeta larvae & 63 & 2.62 & 74 & 8.52 & 35 & 6.10 \\
\hline 17 & Gastropod larvae & 63 & 2.62 & 15 & 1.73 & 0 & 0.00 \\
\hline
\end{tabular}


Table 3. The mean density of the recorded invertebrate attached to Hormophysa uneiformis, Cystoseira myrica and Sargassum cinereum at the Kalawy Bay area.

\begin{tabular}{|c|l|c|c|c|c|c|c|}
\hline \multicolumn{2}{|l|}{ Seaweed species } & C.myrica & RA & H. uneiformis & RA & S.cinereum & RA \\
\hline NO. & Invertebrate Taxa & Indv. /g & $\%$ & Indv. /g & \% & Indv./g & \% \\
\hline 1 & Tintinnopsis campanula & 29 & 3.98 & 0 & 0.00 & 0 & 0.00 \\
\hline 2 & Globigerina inflata & 43 & 5.90 & 36 & 3.77 & 71 & 6.99 \\
\hline 3 & Nematoda sp. & 286 & 39.23 & 250 & 26.18 & 271 & 26.67 \\
\hline 4 & Pleopis polyphemoides & 0 & 0.00 & 24 & 2.51 & 0 & 0.00 \\
\hline 5 & Podon sp. & 0 & 0.00 & 24 & 2.51 & 0 & 0.00 \\
\hline 6 & Evadne nordmanni & 0 & 0.00 & 0 & 0.00 & 29 & 2.85 \\
\hline 7 & Oncaea conifer & 0 & 0.00 & 24 & 2.51 & 0 & 0.00 \\
\hline 8 & Euterpina acutifrons & 114 & 15.64 & 179 & 18.74 & 29 & 2.85 \\
\hline 9 & Microsetella norvegica & 0 & 0.00 & 0 & 0.00 & 100 & 9.84 \\
\hline 10 & Microsetella rosea & 0 & 0.00 & 0 & 0.00 & 43 & 4.23 \\
\hline 11 & Nauplius larvae & 0 & 0.00 & 0 & 0.00 & 29 & 2.85 \\
\hline 12 & Copepodite stages & 57 & 7.82 & 24 & 2.51 & 29 & 2.85 \\
\hline 13 & Cypridina sp. & 71 & 9.74 & 167 & 17.49 & 243 & 23.92 \\
\hline 14 & Euphilomedes interpuncta & 29 & 3.98 & 0 & 0.00 & 0 & 0.00 \\
\hline 15 & Amphipod larvae & 71 & 9.74 & 179 & 18.74 & 86 & 8.46 \\
\hline 16 & Polychaetae larvae & 0 & 0.00 & 48 & 5.03 & 86 & 8.46 \\
\hline 17 & Gastropod larvae & 29 & 3.98 & 0 & 0.00 & 0 & 0.00 \\
\hline
\end{tabular}

Table 4. The mean density of the recorded invertebrate attached to Caulerpa racemosa, Sargassum cinereum, Cystoseira myrica and Digenia simplex at the NIOF area.

\begin{tabular}{|c|l|c|c|c|c|c|c|c|}
\hline \multicolumn{2}{|c|}{ Seaweed species } & C. myrica & RA & C. racemosa & RA & S. cinereum & RA & D. simplex \\
\hline NO. & Invertebrate Taxa & Indv. /g & $\%$ & Indv./g & $\%$ & Indv./g & \% & Indv. /g \\
\hline 1 & Tintinnopsis campanula & 0 & 0.000 & 82 & 6.376 & 0 & 0.000 & 0 \\
\hline 2 & Globigerina inflata & 52 & 5.014 & 96 & 7.465 & 31 & 4.324 & 94 \\
\hline 3 & Nematoda sp. & 134 & 12.922 & 397 & 30.871 & 99 & 13.808 & 89 \\
\hline 4 & Podon sp. & 45 & 4.339 & 0 & 0.000 & 0 & 0.000 & 20 \\
\hline 5 & Oithona nana & 30 & 2.893 & 0 & 0.000 & 0 & 0.000 & 0 \\
\hline 6 & Farranula gibbula & 15 & 1.446 & 0 & 0.000 & 15 & 2.092 & 0 \\
\hline 7 & Euterpina acutifrons & 0 & 0.000 & 0 & 0.000 & 92 & 12.831 & 0 \\
\hline 8 & Microsetella norvegica & 67 & 6.461 & 110 & 8.554 & 76 & 10.600 & 168 \\
\hline 9 & Microsetella rosea & 0 & 0.000 & 82 & 6.376 & 61 & 8.508 & 54 \\
\hline 10 & Nauplius larvae & 7 & 0.675 & 0 & 0.000 & 23 & 3.208 & 35 \\
\hline 11 & Copepodite stages & 15 & 1.446 & 68 & 5.288 & 61 & 8.508 & 59 \\
\hline 12 & Cypridina sp. & 0 & 0.000 & 178 & 13.841 & 61 & 8.508 & 198 \\
\hline
\end{tabular}




\begin{tabular}{|c|l|c|c|c|c|c|c|c|}
\hline 13 & Amphipod larvae & 433 & 41.755 & 68 & 5.288 & 84 & 11.715 & 64 \\
\hline 14 & Polychaetae larvae & 112 & 10.800 & 82 & 6.376 & 53 & 7.392 & 35 \\
\hline 15 & Gastropod larvae & 0 & 0.000 & 0 & 0.000 & 0 & 0.000 & 40 \\
\hline 16 & Zoea larvae & 0 & 0.000 & 82 & 6.376 & 0 & 0.000 & 0 \\
\hline 17 & Cirripede nauplii & 127 & 12.247 & 0 & 0.000 & 61 & 8.508 & 0 \\
\hline 18 & Fish larvae & 0 & 0.000 & 41 & 3.188 & 0 & 0.000 & 0 \\
\hline
\end{tabular}

Richness and Shannon-Wiener diversity of the recorded invertebrate taxa

The highest peak value of the taxa richness was recorded in $C$. myrica at the Mangrove area (14 taxa), while 11 taxa and 12 taxa were recorded in S. cinereum at Kalawy Bay and NIOF areas, respectively. Shannon-Wiener's diversity index ranged between 1.67 in H. tuna to 2.94 in H. cuneiformis at the Mangrove area. At Kalawy Bay, Shannon-Wiener's diversity index ranged between 2.03 and 2.35 in C. myrica and $S$. cinereum, respectively. Additionally, at NIOF area, the Shannon-Wiener's diversity index ranged between 1.76 and 2.42 in D. simplex and S. cinereum, respectively. Taxa richness and the Shannon-Wiener diversity index $\left(\mathrm{H}^{\prime}\right)$ of the recorded invertebrate are presented in Fig. 4.

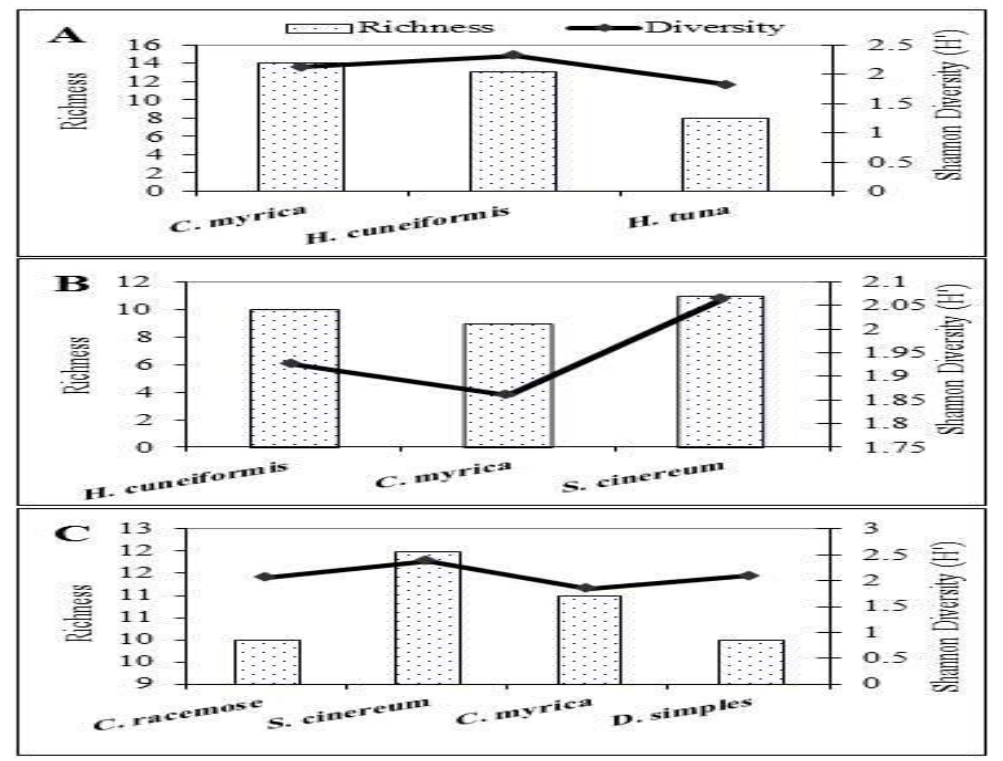

Fig. 4. Richness and Shannon-Wiener diversity Index ( $\left.\mathrm{H}^{\prime}\right)$ of recorded invertebrate at the three studied locations. A: Mangrove Area.B:

Kalawy Bay Area C: NIOF area. 


\section{Effect of physicochemical parameters on invertebrate abundance}

The results of canonical correspondence analysis (CCA) revealed that an abundance of the collected invertebrate groups was mostly related to the physicochemical parameters (Fig. 5). Water temperature, pH, TDS, conductivity, salinity and $\mathrm{SiO}_{2}$ had positive effect on the abundance of the annelids and protozoan, and negative effect on the amphipods and ostracods. $\mathrm{PO}_{4}$ and $\mathrm{NO}_{3}$ had a positive effect on amphipods and Ostracoda, Mollusca, and Copepoda. DO and turbidity had positive effect on the abundance of Platyhelminthes, while they had a negative effect on the cladocerans, molluscans and copepods groups. $\mathrm{NH}_{4}$ had a positive effect only on Cladocerans.

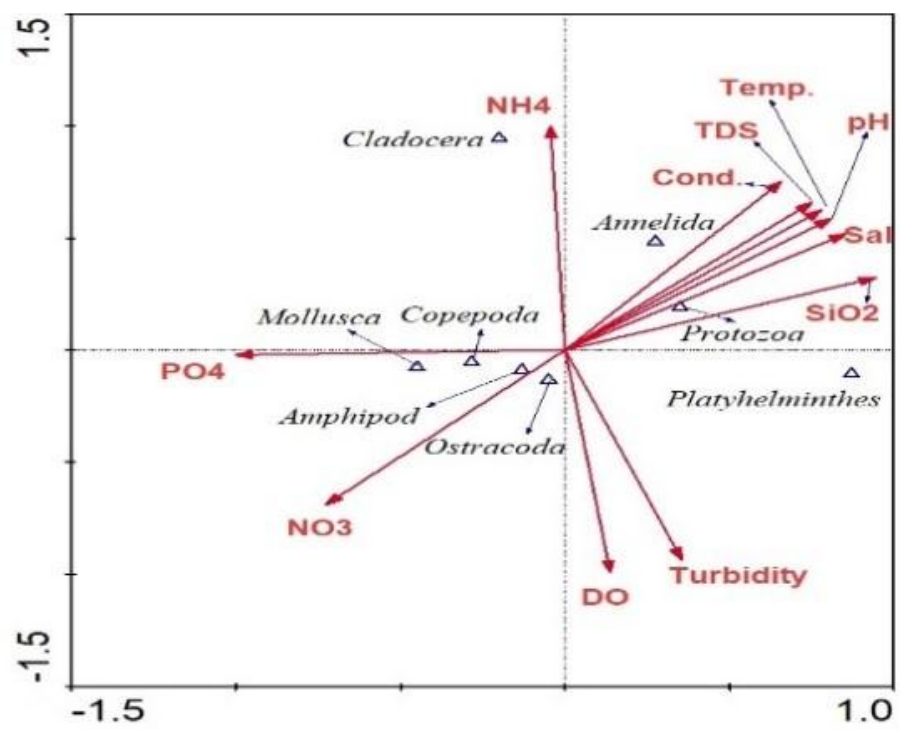

Fig. 5. The canonical correspondence analysis (CCA) results on physicochemical parameters and invertebrate group abundances in study sites. Physicochemical parameters notation: Temp $=$ water temperature, Cond $=$ Conductivity, Sal=Salinity, Turb $=$ Turbidity, $\mathrm{DO}=$ Dissolved Oxygen, $\mathrm{NH}_{4}=$ Ammonia, $\mathrm{NO}_{3}=$ Nitrate, $\mathrm{NO}_{2}=$ Nitrite, $\mathrm{PO}_{4}=$ Phosphate and $\mathrm{SIO}_{2}=$ Silicate

\section{DISCUSSION}

An epiphyte is a living being that develops on the outside of a plant and gets its moisture and supplements from the air, rain, water (in marine environments) or from debris conforming to it (Hickey \& King, 2001). Epiphytes are different living beings including animals, fungi, bacteria, and myxomycetes with a rich and various living space (Sydney et al., 2009). Settlement of epiphytic species is affected by certain components including light, temperature, currents, nutrients, and trophic interactions. Algae are viewed as the most well-known substrates gathering epiphytes in marine biological systems (Larkum et al., 2006). 
The present study was carried out in the winter season, water temperature ranged from $17.59-20.93^{\circ} \mathrm{C}$. As a result, there was a similar influence of the environmental factors, which were represented by the physicochemical parameters, on the abundance and distribution of the recorded invertebrates. Dai et al. (2014) reported that some invertebrate species, preferring cold water, could not be detected in the collected assemblages. Moreover, they did not vary among different sampling locations, thus indicating the non-significant differences of environmental factors. Consequently, the effect of the physicochemical parameters on the abundance of the invertebrate taxa group had almost the same influence in all studied locations. Lemieux and Cusson (2014) stated that habitat-forming species diversity profiles had a limited short-term function in their study habitat, and this indicated that biological forcing in these intertidal communities is less vital than environmental conditions.

There are other factors that may influence the differences in number of individuals per algal unit. Lippert et al. (2001) stated that biotic and abiotic factors can affect the invertebrates to attach on different species of macroalgae and these factors may be different for either sessile or mobile fauna. Hayward (1980) reported that the structural qualities of algae like size, surface or thallus structure may be considered as an important biotic factor. Previous studies of Whorff et al. (1995) and Kelaher (2000) illustrated that the diversity and abundance of macrofauna frequently vary among patches of algal turf on rocky intertidal shores.

Tavares et al. (2013) stated that the main reasons affecting the selection of marine macrophytes by meso-herbivores are not clear, and may incorporate the nutritional nature of algae, the estimation of the living space as shelter, and the accessibility of algae in the environment. The present investigation revealed that there was a distinct relationship between the abundance of invertebrate species and the species of seaweed. Taylor and Cole (1994) reported that differences in the morphology of the plants should be considered for most of the variation in epifaunal densities among the investigated algal species.

The present study revealed that the amphipod larvae were the most abundant invertebrates at the Mangrove area. Klumpp et al. (1992) revealed that the impacts of amphipods and other meso-herbivores on macrophytes are the base elements of these environments supporting the cycling of nutrients. Wakabara et al. (1996) stated that the density of amphipod predators is higher in the colder months, which would expand the predation stress on the amphipods.

The highest peak value for the taxa richness (14) was recorded in the seaweed species Cystoseira myrica at the Mangrove area. Bouillon et al. (2000) reported that mangrove forests are highly productive tropical ecosystems. Able (2005) stated that mangrove forests have an essential role in marine fisheries, such as feeding ground, 
nursery ground, and spawning ground for different kinds of aquatic biota. This result may conclude that the richness of the taxa is affected only by the difference in seaweed species habitat in this case. Bates (2007) manipulates experiments over 2 years to determine the implications of varied combinations of seaweed species richness, functional richness, and species and functional composition on the structure of associated mobile epifaunal assemblages. The aforementioned author reported that invertebrates' epifaunal richness and abundance are not influenced by differences in the biodiversity of seaweeds. Lemieux and Cusson (2014) did not notice a remarkable change in habitatforming species richness, evenness, abundance, or identity of associated species community.

\section{CONCLUSION}

The present study focused on the invertebrates associated with some of the dominant macroalgae species at three locations along the Red Sea, Egypt. The study of diversity revealed that the highest value for species richness was recorded for $C$. myrica at the Mangrove area, while the highest values for Sargassum cinereum were recorded at Kalawy Bay and NIOF areas. The study was conducted merely in the season of winter; hence, results might have shown slight differences between both species and locations.

\section{REFERENCES}

Able KW. (2005). A re-examination of fish estuarine dependence: Evidence for connectivity between estuarine and ocean habitats. Estuar Coast Shelf Sci 64: 5-17.

APHA. (2005). Standard Methods for the Examination of Water \& Wastewater, American Public Health Association.

Bates, Colin R.; De Wreed and Robert E. (2007). Do changes in seaweed biodiversity influence associated invertebrate epifauna. Journal of Experimental Marine Biology and Ecology 344: 206-214.

Bouillon, S.; Mohan P.C.; Sreenivas, N. and Dehairs, F. (2000). Sources of suspended organic matter and selective feeding by zooplankton invertebrate in an estuarine Mangrove ecosystem as traced by stable isotopes. Marine Ecology-Progress Series, 208: 79-92.

Bracken, E.S. Matthew; Cirse, A. Gonzalez Dorantes and Tachowicz, John J. S. (2007). Whole-community mutualism: associated invertebrates facilitate a dominant habitat-forming seaweed. Ecology, pp. 2211-2219 by the Ecological Society of America.

Bradford-Grieve, j. M. and Jillett, J. B. (1980). The marine fauna of New Zealand: pelagic calanoid copepods: Family Aetideidae. Memoirs. N. Z. Oceanographic Institute 86: 1-102. 
Bradford-Grieve, J. M. (1972). Systematics and ecology of New Zealand Central East Coast sampled at Kaikoura. Memoirs. N. Z. Oceanograpgic Institute 54:1-82.

Bradford-Grieve, J. M. (1994). The marine fauna of New Zealand: pelagic calanoid Copepoda: Megacalanidae, Calanidae, Paracalanidae, Mecynoceridae, Eucalanidae, Spinocalanidae, Clausocalanidae. Wellington NIWA. ISSN, 0083-7903; 102.

Bradford-Grieve, j. M.; Haakonsen, L. and Jillett, J. B. (1983). The marine fauna of New Zealand: pelagic calanoid copepods: Families Euchaetidae, Phaemidae, Scolecithricidae, Diaixidae and Tharybidae. Memoirs. N. Z. Oceanographic Institute, 90: $1-150$.

Daia Li-li; b, Gonga Ying-chun, LicXue-mei, Fenga Wei-song and Yua Yu-he, (2014). Influence of environmental factors on zooplankton invertebrate assemblages in Bosten Lake, a large oligo saline lake in arid northwestern China. Science Asia 40: 1-10.

Done, T. J.; J. C. Ogden; W. J. Weibe and B. R. Rosen. (1997). Biodiversity and ecosystem function of coral reefs. pp. 393-429 in H. A. Mooney, J. H. Cushman, E. Medina, O. E.

Ellison, A. M.; Farnsworth, E. J. and Twilley, R. R. (1996). Facultative mutualism between red Mangroves and root- fouling sponges in Belizean mangal. Ecology 77:24312444.

Grabowski, J. H.; A. R. Hughes; D. L. Kimbro and M. A. Dolan. (2005). How habitat setting influences restored oyster reef communities. Ecology 86:1926-1935.

Graham, M. H. (2004). Effects of local deforestation on the diversity and structure of Southern California giant kelp forest food webs. Ecosystems 7:341-357.

Hayward, PJ, (1980). Invertebrates epiphytes of coastal marine algae. In Price JH, Irvine DEG, Farnham WF (eds) the shore environment, ecosystems. Academic Press, London, PP 761- 787.

Heck, K. L., Jr., and L. B. Crowder. (1991). Habitat structure and predator-prey interactions in vegetated aquatic ecosystems. P 281-299 In S. S. Bell, E. D. McCoy, and E. R. Mushinsky, editors. Habitat structure of objects in space. Chapman and Hall, London, UK.

Heron, G. A. and Bradford-Grieve, J. M. (1995). The marine fauna of New Zealand: Pelagic Copepoda: Poecilostomatoida: Oncaeidae. Memoirs. N. Z. Oceanographic Institute 104:1-57.

Hickey, M.; King, C., (2001). The Cambridge Illustrated Glossary of Botanical Terms. Cambridge University Press. 
Kelaher, B. (2000). Biodiversity of macrofauna assemblages in Coralline algal turf. PhD thesis, university of Sydney, Sydney, Australia.

Klumpp, D.W.; Salita-Espinosa, J.T. and Fortes, M.D. (1992). The role of epiphytic periphiton and macroinvertebrate grazer in the trophic flux of a tropical seagrass community. Aquatic Botany, 43: 327-349.

Larkum, A.W.D.; Orth, R.J. and Duarte. C.M. (2006). Seagrasses: Biology, Ecology and Conservation. Springer.

Lemieux J, and Cusson M. (2014). Effects of Habitat-Forming Species Richness, Evenness, Identity, and Abundance on Benthic Intertidal Community Establishment and Productivity. PLoS ONE 9(10): e109261. doi: 10.1371/journal.pone.0109261.

Lippert, H; Iken, H and Wiencke, C. (2001). Macrofauna associated with macroalgae in the Kingsfjord (Spitsbergen). Polar Biol, 24: 512-522.

Michel, H. B.; Behbehani, M. and Herring, D. (1986). Zooplankton of the Western Arabia Gulf south of Kuwait waters. Kuwait Bull. Mar. Sci.; 8: 1-37.

Mori, T. (1964). The pelagic Copepoda from the neighboring waters of Japan. 2nd Edn. The Soyo Campany Inc., Tokyo. 150 pp.

Newell, W. T. and Newell, R. C. (1977). Marine plankton, a practical guide. Hutchinson Co. Ltd.: 244 pp.

Österling, M. and Pihl, L. (2001). Effects of filamentous green algal mats on benthic macrofaunal functional feeding groups. J. Exp. Mar. Biol. Ecol., 263(2): 159-183.

Pereira, S. G.; Lima, F. P.; Queiroz, N. C.; Ribeiro, P. A. and Santos, A.M. (2006). Biogeographic patterns of intertidal macroinvertebrates and their association with macroalgae distribution along the Portuguese coast. Hydrobiologia, 555: 185-192.

Russo, A. R. (1997). Epifauna living on sublittoral seaweeds around Cyprus. Hydrobiologia 344: 169-179.

Salovius, S. and Kraufvelin, P. (2004). Animal diversity in Baltic rock shore macroalgae: Can Cladophora glomerata compensate for lost Fucus vesiculosus. Estuar. Coast. Shelf Sci., 61(2): 369-378.

Salovius, S.; Nyqvist, M. and Bonsdorff, E. (2005). Life in the fast lane: Macrobenthos use temporary drifting algal habitats. J. Sea Res., 53(3), 169-180. 
Sánchez-Moyano, J.E.; García-Asencio, E.M.and García-Gómez, J.C. (2007). Effects of temporal variation of the seaweed Caulerpa prolifera cover on the associated crustacean community. Mar. Ecol. 28: 324-337.

Sydney E. Everhart; Joseph S. Ely and Harold W. Keller. (2009). Evaluation of tree canopy epiphytes and bark characteristics associated with the presence of corticolous myxomycetes. Botany. 87 (5): 509-517. Doi:10.1139/b09-027. Archived from the original (PDF) on 2013-09-26.

Tavares, Mauro Rezende, Henrique Grande and Giuliano Buzá Jacobucci. (2013). Habitat and food selection by herbivorous amphipods associated with macroalgal beds on the southeast coast of Brazil. Nauplius 21(1): 09-15.

Taylor, R.B. and Cole, R.G. (1994). Mobile epifauna on subtidal brown seaweeds in northeastern New Zealand. Marine Ecology Progress Series, 115: 271-282.

Wakabara, Y.; Flynn, M. and Tararam, A.S. (1996). Ingestion and selection of suprabenthic crustaceans by small-sized fishes in a lower saltmarsh system. Revista Brasileira de Oceanografia, 44: 89-103.

Whorff, J.S.; Whorff, L.L. and Sweet, M.H. (1995). Spatial variation in an algal turf community with respect to substratum slope and wave height. Journal of marine Biological Association of the United Kingdom, 55: 45-67.

Williamson, D. I. (1967). On a collection of plankton Decapoda and Stomatopoda (Crustacea) from the Mediterranean coast of Israel. Sea Fish. Res. Sta. Haifa Bill., 45: 132. 